ПРЕГЛЕДНИ РАДОВИ

ОБЗОРНЫЕ СТАТЬИ

REVIEW PAPERS

\title{
BETA FUNCTIONS IN THE QUANTUM FIELD THEORY
}

\section{Nicola Fabiano}

University of Belgrade, "Vinča" Institute of Nuclear Sciences Institute of National Importance for the Republic of Serbia,

Belgrade, Republic of Serbia,

e-mail: nicola.fabiano@gmail.com,

ORCID iD: (1) https://orcid.org/0000-0003-1645-2071

DOI: 10.5937/vojtehg70-32131;https://doi.org/10.5937/vojtehg70-32131

FIELD: Mathematics

ARTICLE TYPE: Review paper

Abstract:

Introduction/purpose: The running of the coupling constant in various Quantum Field Theories and a possible behaviour of the beta function are illustrated.

Methods: The Callan-Symanzik equation is used for the study of the beta function evolution.

Results: Different behaviours of the coupling constant for high energies are observed for different theories. The phenomenon of asymptotic freedom is of particular interest.

Conclusions: Quantum Electrodynamics (QED) and Quantum Chromodinamics (QCD) coupling constants have completely different behaviours in the regime of high energies. While the first one diverges for finite energies, the latter one tends to zero as energy increases. This QCD phenomenon is called asymptotic freedom.

Key words: Quantum Electrodynamics, Quantum Chromodynamics, Quantum Field Theory, renormalization group, beta function.

\section{Fixed points}

In (Fabiano, 2021) we have seen how a generic coupling constant behaves at different renormalisation scales. It should be remarked that this result is valid also for different renormalisation schemes, not only for dimensional regularisation. In this sense the coupling constant is a func- 
tion depending on the energy scale $\mu$, and is often regarded to as running coupling constant. Just for the sake of simplicity define the new variable $t=\log \mu$ (the $t$ variable could be also thought of as a "time" parameter). With this position, the Callan-Symanzik equation (Callan, 1970; Symanzik, 1970) could be rewritten in a nicer form as:

$$
\frac{d g}{d t}=\beta(g)
$$

which is a differential equation governing the behaviour of the coupling constant $g$ upon the energy scale considered. As such it also needs some initial conditions in order to be solved - a Cauchy problem. The points $\bar{g}$ for which

$$
\beta(\bar{g})=0
$$

are called fixed points (Symanzik, 1971), and once the coupling $g$ reaches one of these points, it does not evolve anymore. In Fig. (1) a possible scenario for the $\beta$ function is shown. The origin 0 , the points $g_{1}$ and $g_{2}$ are fixed points. If for the initial scale $t=0$ the coupling constant $g$ is at one of these points, then it will remain there for any energy scale considered (or "forever", depending on the language one prefers).

There are different kinds of fixed points. Consider the point $g_{1}$ and its neighbourhood. From the Figure, for $0<g<g_{1}, \beta(g)>0$ then the coupling constant increases with the scale because of eq. (2) (i.e. $d g / d t>0$ ), moving towards $g_{1}$ for $t \rightarrow+\infty$. On the contrary, in the interval $g_{1}<g<g_{2}$ the $\beta$ function is negative, so the coupling constant decreases and approaches again $g_{1}$ as $t \rightarrow+\infty$. We conclude that $g_{1}$ is a stable fixed point, as $g$ tends to it from either side. It is called the ultraviolet stable fixed point - the term "ultraviolet" is present because $g \rightarrow g_{1}$ as $t \rightarrow+\infty$.

On the other hand, for the points 0 and $g_{2}$ it is clear that the inverse of the previous argument holds true: the coupling $g$ "escapes" from them as $t \rightarrow+\infty$, and approaches them as energy decreases, for $t \rightarrow 0$. Such points are named the infrared stable fixed points.

It is important to know that the fixed points of the $\beta$ function are difficult to calculate because they are usually determined by nonperturbative effects, apart from the trivial zero at the origin, for $g=0$.

\section{Behaviour of $\beta$ function}

We shall consider some possible asymptotic behaviours of the $\beta$ function for energy scale $\mu \rightarrow+\infty$. The exact problem we consider is given 


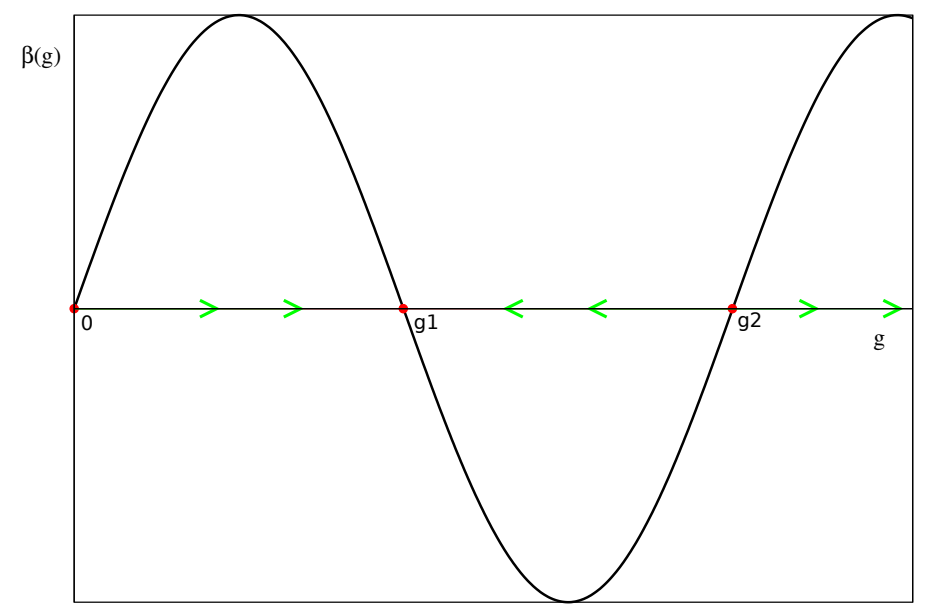

Figure 1 - The Beta function with fixed points $0, g_{1}$ and $g_{2}$. The arrows indicate the direction of the flow of $g$ with increasing scale $\mu$

Puc. 1 - Бета-фрункция с фриксированными точками $0, g_{1}$ u $g_{2}$. Стрелки указывают направление потока $g$ с увеличением шкалы $\mu$

Слика 1 - Бета фрункција са фриксним тачкама $0, g_{1}$ u $g_{2}$. Стрелице показују правац тока g са повећањем скале $\mu$

by

$$
\begin{gathered}
\mu \frac{d g}{d \mu}=\beta(g) \\
g\left(\mu_{0}\right)=g_{0},
\end{gathered}
$$

whose formal solution is written as

$$
\int_{g_{0}}^{g} \frac{\mathrm{d} g}{\beta(g)}=\log \left(\frac{\mu}{\mu_{0}}\right) \text {. }
$$

Different behaviours of the $\beta$ function are shown in Fig. 2 .

For such functions, the running coupling constant $g$ will, for different cases:

(a) approach infinity for a finite value of $g$, with $\beta(g)>0$ 


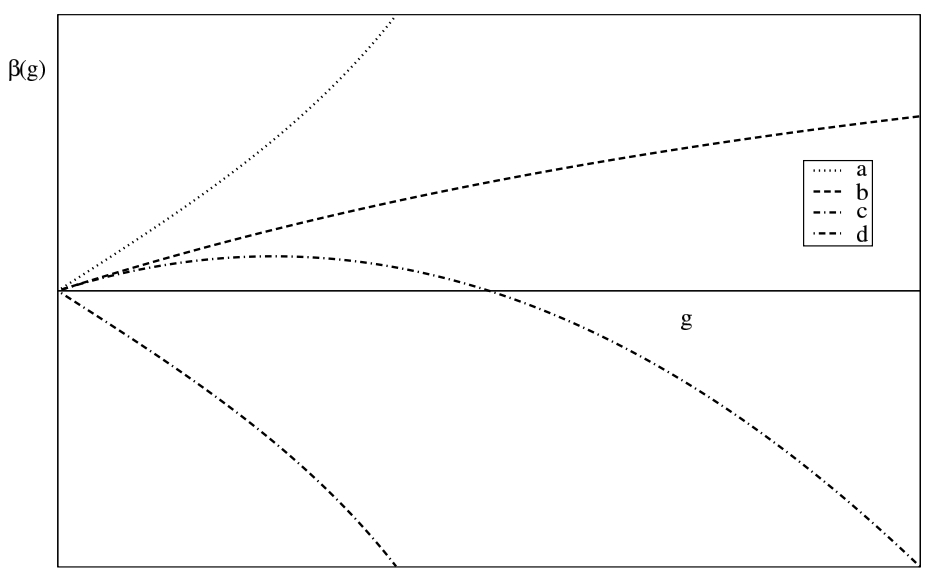

Figure 2 - Beta functions with different asymptotic behaviour Pис. 2 - Бета-фрункции с различным асимптотическим поведением Слика 2 - Бета функције с различитим асимптотским понашањем

(b) approach infinity as $g \rightarrow+\infty$

(c) have a finite fixed point in $g_{1}, \beta\left(g_{1}\right)=0$

(d) approach $-\infty$ for increasing $g$, with $\beta(g)<0$.

\section{Case (a)}

Suppose that $\beta(g)$ grows sufficiently rapidly in such a manner that the integral of eq. (4) converges (for instance, any power of $g$ larger than 1 ), namely

$$
\int^{+\infty} \frac{\mathrm{d} g}{\beta(g)}<+\infty,
$$

then it is clear that the scale $\mu$ has a finite upper bound $\mu_{+\infty}$ corresponding to the coupling $g=+\infty$ given by the relation

$$
\mu_{+\infty}=\mu_{0} \exp \left(\int_{g_{0}}^{+\infty} \frac{\mathrm{d} g}{\beta(g)}\right) .
$$


We have already encountered such behaviour, for the QED coupling case as discussed in (Fabiano, 2021), where $\beta(g)=g^{3} / 12 \pi^{2}$ and $\mu_{+\infty}$ is given by the Landau pole (Landau et al, 1954; Landau \& Pomeranchuk, 1955) of eq. (40) in (Fabiano, 2021).

Another example is the scalar field theory with the interaction term $g \phi^{4} / 4$ ! given by the Lagrangian

$$
\mathcal{L}=\frac{1}{2}(\partial \phi)^{2}-\frac{m^{2}}{2 !} \phi^{2}-\frac{g}{4 !} \phi^{4},
$$

for which the $\beta$ function is

$$
\beta(g)=\frac{3 g^{2}}{16 \pi^{2}}-\frac{18}{3} \frac{g^{3}}{\left(16 \pi^{2}\right)^{2}}+\mathcal{O}\left(g^{4}\right) .
$$

The Lagrangian (7) is almost the same of the Higgs field in the Standard Model (Glashow, 1959; Salam \& Ward, 1959; Weinberg, 1967). The only difference, yet an essential one, is that in the latter case the scalar field is coupled to fermion fields $\psi$ via a term $\lambda \bar{\psi} \phi \psi$, so called Yukawa coupling (Yukawa, 1935), where $\lambda$ is another coupling constant different from $g$.

Using only the first term of eq. (8), we arrive at the expression

$$
g=\frac{g_{0}}{1-\frac{3}{16 \pi^{2}} g_{0} \log \left(\frac{\mu}{\mu_{0}}\right)},
$$

which has the same form of eq. (39) in (Fabiano, 2021) as anticipated; it has also a pole for $\mu=\mu_{0} \exp \left(16 \pi^{2} /\left(3 g_{0}\right)\right)$.

\section{Case (b)}

The integral of eq. (5) diverges. It means that the coupling constant $g$ becomes infinite only at an infinite energy scale, $\mu=+\infty$. For instance, assume that $\beta(g)=a g^{k}$, with $a>0$ and $k<1$ but $k \neq-1$ - then one obtains for eq. (3) the solution

$$
g=\left[g_{0}^{1-k}+a(1-k) \log \left(\frac{\mu}{\mu_{0}}\right)\right]^{1 /(1-k)} .
$$

The growth of $g$ in $\mu$ is very slow, but in the very high energy limit the coupling becomes independent from the initial condition $g_{0}$. 


\section{Case (c)}

We encounter a fixed point like previously discussed in the section Fixed points for the ultraviolet fixed point $g_{1}$, that is $\beta\left(g_{1}\right)=0$. The $\beta$ function stays positive for $0<g<g_{1}$ and turns negative afterwards. Either if the initial condition $g_{0}$ is such that $g_{0}<g_{1}$ or $g_{0}>g_{1}$ the coupling constant $g$ will evolve towards the fixed point, $g \rightarrow g_{1}$ as $\mu \rightarrow+\infty$.

Assuming that the root of $\beta$ in $g_{1}$ is simple, then

$$
\beta(g)=a\left(g_{1}-g\right) \text { for } g \rightarrow g_{1}
$$

with $a>0$. The solution to eq. (3) is then

$$
g_{1}-g \sim \mu^{-a}
$$

with the assumption that $g_{0}<g, g_{0}<g_{1}$ and $g<g_{1}$.

It is worth noticing that we have already discussed a case in which, apparently, an ultraviolet fixed point is obtained. The $\phi^{4}$ scalar theory presents such a point. From eq. (8) one computes the fixed point $g_{1}$ as

$$
g_{1}=8 \pi^{2},
$$

which, however, has a huge value of $g_{1} \approx 80$ thus spoiling the perturbation theory as $g \gg 1$. As the $\beta$ functions that have been encountered so far have been computed using only the perturbation theory, it is clear that the result obtained above is invalid. The discussion regarding eq. (8) proves the statement of the section Fixed points, for which a fixed point could be basically only computed by means of nonperturbative techniques.

\section{Case (d)}

So far, all $\beta$ functions discussed were positive at least for small positive $g$, so the renormalisation group flow drives away $g(\mu)$ from the origin $g=0$. Now suppose that $\beta(g)<0$ for small positive $g$, like

$$
\beta(g)=-a g^{n},
$$

where $a>0, n>1$ and an integer. The solution to eq. (3) is then written as

$$
g=\frac{g_{0}}{\left[1+g_{0}^{n-1}(n-1) a \log \left(\frac{\mu}{\mu_{0}}\right)\right]^{1 /(n-1)}} .
$$


A dramatic difference between this and the previous cases is that, for large energy scales, the coupling constant vanishes, i.e.

$$
g=0 \text { for } \mu \rightarrow+\infty .
$$

This phenomenon is called asymptotic freedom (Gross \& Wilczek, 1973; Politzer, 1973). With growing energy, the theory has a weaker coupling constant, approximating a free theory, i.e. one without interactions. So at larger energy scales, the perturbation theory gives better results. Remember actually that corrections $C$ of any kind (propagator, coupling, etc.) are computed as series of powers of $g$,

$$
C=\sum_{n} c_{n} g^{n}
$$

and this formal series is supposed to converge for small $g$.

A toy model that exhibits asymptotic freedom could be obtained from the Lagrangian (7) with a negative potential ${ }^{1}-g \phi^{4} / 4$ !. Its $\beta$ function has the form

$$
\beta(g)=-\frac{3}{16 \pi^{2}} g^{2}
$$

for which

$$
g=\left[\frac{3}{16 \pi^{2}} \log \left(\frac{\mu}{\mu_{0}}\right)\right]^{-1} \text { for } \mu \rightarrow+\infty .
$$

i.e. $g$ goes to zero at logarithmic speed.

A very important class of theories that have the property of asymptotic freedom is the Yang-Mills theory (Yang \& Mills, 1954), with the gauge group $S U(N)$. Of particular relevance is one of them, quantum chromodynamics - QCD - that is the theory of strong interactions embedded in the Standard Model, whose gauge group is $S U(3)$.

The QCD Lagrangian is written as

$$
\mathcal{L}=\bar{\psi}_{j}\left[i\left(\gamma^{\mu} \mathcal{D}_{\mu}\right)_{j k}-m \delta_{j k}\right] \psi_{k}-\frac{1}{4} G_{\mu \nu}^{a} G_{a}^{\mu \nu}
$$

where $\psi_{j}(x)$ is the $j$-th quark field, indexed by $j, k ; A_{\mu}^{a}$ are the gluon fields, $a=1 \ldots 8 . \gamma^{\mu}$ are the usual Dirac matrices, the covariant derivative is given

\footnotetext{
${ }^{1}$ We neglect the fact that this theory is ill-defined and that the perturbation theory cannot be applied.
} 
by $\mathcal{D}_{\mu}=\partial_{\mu}-i g A_{\mu}^{a} T^{a} . G_{\mu \nu}^{a}$ is the gluon field strength tensor, similar to the $F_{\mu \nu}$ electromagnetic tensor, defined by

$$
G_{\mu \nu}^{a}=\partial_{\mu} A_{\nu}^{a}-\partial_{\nu} A_{\mu}^{a}+g f^{a b c} A_{\mu}^{b} A_{\nu}^{c}
$$

where $f^{a b c}$ are the structure constants of $S U(3),\left[T^{a}, T^{b}\right]=i f^{a b c} T^{c}$, with $T^{a}$ being generators of the group.

For a generic $S U(N)$ the Yang-Mills theory coupled to fermions the $\beta$ function at one-loop level is given by

$$
\beta(g)=-\frac{g^{3}}{4 \pi^{2}}\left(\frac{11}{12} N-\frac{1}{3} C_{2}\right)+\mathcal{O}\left(g^{5}\right),
$$

and for the QCD case $C_{2}=n_{f} / 2$,

$$
\beta(g)=-\frac{g^{3}}{8 \pi^{2}}\left(\frac{11}{2}-\frac{n_{f}}{3}\right)+\mathcal{O}\left(g^{5}\right),
$$

where $n_{f}$ is the number of quark flavours with masses much lower than the energy scale considered $\mu$, which can be considered massless.

Defining the QCD strong coupling constant $\alpha_{s}=g^{2} / 4 \pi^{2}$ in an analogous fashion to QED, where $\alpha=e^{2} / 4 \pi$, we obtain from eq. (49) in (Fabiano, 2021)

$$
\alpha_{s}(\mu)=\frac{12 \pi}{\left(33-2 n_{f}\right) \log (\mu / \Lambda)}
$$

which exhibits asymptotic freedom as far as the number of quark flavours is $n_{f}<17$. Another property due to the presence of (approximately) massless particles is that a dimensionless coupling $g_{0}$ is exchanged for a dimensionful parameter $\Lambda$, which is an integration constant with dimensions of energy. This phenomenon is referred to as dimensional transmutation (Coleman \& Weinberg, 1973; Weinberg, 1973). The $\beta$ function eq. (24) is known today to four-loop order $\mathcal{O}\left(\alpha_{s}^{4}\right)$, with three and four-loop coefficients being renormalisation scheme dependent. The measured value of a strong coupling constant at the $Z$ peak is

$$
\alpha_{s}\left(m_{Z}\right)=0.1197 \pm 0.0016,
$$

while the corresponding value of $\Lambda$ is about $0.2 \mathrm{GeV}$.

A few remarks are in order. In the 1950s, Landau argued that in QED the increasing powers of logarithmic terms, that we already encountered at 
one-loop level in (Fabiano, 2021), of the form $\log (E / M)$, would coalesce and give raise to singularities for finite values of the energy $E$. This is the (a) case, with the Landau poles, also known as the Landau ghosts or the Moscow zero (because $e_{0} / e(\mu)=0$ ), discovered by himself (Landau et al, 1954; Landau \& Pomeranchuk, 1955). This argument does not rule out the cases (b) or (c), though. This possible inconsistency in the renormalisation procedure has not yet been proved but it is believed to actually exist.

Today, there is a broad agreement on the fact that the interacting field theories like QED or scalar $\phi^{4}$ we have discussed (which are not asymptotically free) are not mathematically consistent. About QED, there is some evidence against the case (c) with a finite fixed point that would be only possible in the presence of yet unknown nonperturbative effects. However, even if (c) is ruled out, there still remains the possibility (b) with a fixed point at infinity.

There is an electromagnetic analogy for different behaviours of QED and QCD couplings. In QED, the charge is stronger at shorter distances, i.e. is the vacuum acts like a dielectric medium with a dielectric constant

$$
\varepsilon>1 \text {, }
$$

shielding the charge. Remembering the relation of the relative magnetic permeability $\mu$ to the dielectric constant to the speed of light, which in our units is 1 ,

$$
\varepsilon \mu=1 \text {, }
$$

we have a duality relation. The QED case corresponds to $\mu<1$, also known as Landau diamagnetism, where charged particles in the medium in response to an external magnetic field generate an opposed magnetic field, a phenomenon seen in superconductors, water, copper, and gold. In QCD, the opposite behaviour is observed: the chromoelectric charge is weaker at shorter distances, so its vacuum is anti screening, with a dielectric constant

$$
\varepsilon<1 \text {. }
$$

The equivalent magnetic permeability is $\mu>1$, known as Pauli paramagnetism, where the particles tend to align with the external field, as in tungsten, aluminium, or lithium. It has to be stressed that the electromagnetic terminology used for QCD is just an analogy to the QED case: by "the charge" we mean the colour charge, by "the magnetic moment" the colour magnetic moment. 


\section{References}

Callan, C.G. 1970. Broken Scale Invariance in Scalar Field Theory. Physical Review D, 2(8), pp.1541-1547. Available at: https://doi.org/10.1103/PhysRevD.2.1541.

Coleman, S. \& Weinberg, E. 1973. Radiative Corrections as the Origin of Spontaneous Symmetry Breaking. Physical Review D, 7(6), pp.1888-1910. Available at: https://doi.org/10.1103/PhysRevD.7.1888.

Fabiano, N. 2021. Quantum electrodynamics divergencies. Vojnotehnički glasnik/Military Technical Courier, 69(3), pp.656-675. Available at:

https://doi.org/10.5937/vojtehg69-30366.

Glashow, S. 1959. The renormalizability of vector meson interactions. Nuclear Physics, 10(February-May), pp.107-117. Available at: https://doi.org/10.1016/0029-5582(59)90196-8.

Gross, D.J. \& Wilczek F. 1973. Asymptotically Free Gauge Theories. I. Physical Review D, 8(10), pp.3633-3652. Available at: https://doi.org/10.1103/PhysRevD.8.3633.

Landau, L.D., Abrikosov, A.A. \& Khalatnikov, I.M. 1954. Dokl. Akad. Nauk SSSR, 95, 497, 773, 1177 (in Russian).

Landau, L.D. \& Pomeranchuk, I.Ya. 1955. Dokl. Akad. Nauk SSSR, 102, 489 (in Russian).

Politzer, H.D. 1973. Reliable Perturbative Results for Strong Interactions? Physical Review Letters, 30(26) pp.1346-1349. Available at: https://doi.org/10.1103/PhysRevLett.30.1346.

Salam, A. \& Ward, J.C. 1959. Weak and electromagnetic interactions. II Nuovo Cimento, 11(4), pp.568-577. Available at: https://doi.org/10.1007/BF02726525.

Symanzik, K. 1970. Small distance behaviour in field theory and power counting. Communications in Mathematical Physics, 18(3), pp.227-246. Available at: https://doi.org/10.1007/bf01649434.

Symanzik, K. 1971. Small-distance-behaviour analysis and Wilson expansions. Communications in Mathematical Physics, 23(1), pp.49-86. Available at: https://doi.org/10.1007/BF01877596.

Weinberg, S. 1967. A Model of Leptons. Physical Review Letters, 19(21), pp.1264-1266. Available at: https://doi.org/10.1103/PhysRevLett.19.1264.

Weinberg, S. 1973. New Approach to the Renormalization Group. Physical Review $D, 8(10)$, pp.3497-3509. Available at:

https://doi.org/10.1103/PhysRevD.8.3497.

Yang, C.N. \& Mills, R. 1954. Conservation of Isotopic Spin and Isotopic Gauge Invariance. Physical Review, 96(1), pp.191-195. Available at: https://doi.org/10.1103/PhysRev.96.191.

Yukawa, H. 1935. On the interaction of elementary particles. Proceedings of the Physico-Mathematical Society of Japan. 3rd Series, 17, pp.48-75. Available at: https://doi.org/10.11429/ppmsj1919.17.0_48 . 


\section{БЕТА-ФУНКЦИИ В КВАНТОВОЙ ТЕОРИИ ПОЛЯ}

Никола Фабиано

Белградский университет, Институт ядерных исследований «Винча» - Институт государственного значения для Республики Сербия, г. Белград, Республика Сербия

РУБРИКА ГРНТИ: 29.05.03 Математические методы теоретической физики,

29.05.23 Релятивистская квантовая теория. Квантовая теория поля

29.05.33 Электромагнитное взаимодействие

ВИД СТАТЬИ: обзорная статья

\section{Резюме:}

Введение / цель: В данной статье представлено, как работает константа связи в различных квантовых теориях поля и возможные модели поведения бета-фрнкции.

Методы: Уравнение Каллана-Симанзика используется для изучения эволюции бета-функции.

Результаты: Наблюдается различное поведение константы связи при высоких энергиях в различных теориях. Особый интерес представляет явление асимптотической свободы.

Выводы: Константы связи квантовой электродинамики (КЭД) и квантовой хромодинамики (КХД) ведут себя совершенно по-разному в режиме высоких энергий. Первая отличается конечной энергией, в то время как вторая стремится к нулю, когда энергия увеличивается. Данное явление КХД называется асимптотической свободой.

Ключевые слова: квантовая электродинамика, квантовая хромодинамика, квантовая теория поля, ренормализационная группа, бета-фрункция.

\section{БЕТА ФУНКЦИЈЕ У КВАНТНОЈ ТЕОРИЈИ ПОЉА}

Никола Фабиано

Универзитет у Београду, Институт за нуклеарне науке "Винча"Институт од националног значаја за Републику Србију, Београд, Република Србија 


\author{
ОБЛАСТ: математика \\ ВРСТА ЧЛАНКА: прегледни рад
}

\title{
Сажетак:
}

Увод / циљ: Илустровани су рад константе спреге у разним квантним теоријама поља као и могуће понашање бета функције.

Meтоде: Калан-Шиманзикова једначина користи се за проучавање еволуције бета функције.

Резултати: Примећено је различито понашање константе спреге за високе енергије за различите теорије. Од посебног интереса је френомен асимптотске слободе.

Закључак: Константе спреге квантне електродинамике (QED) и квантне хромодинамике (QCD) имају потпуно ра зличито понашање у режиму високих енергија. Док се прва разилази за коначне енергије, друга тежи нули како се енергија повећава. Овај феномен QCD назива се асимптотска слобода.

Кључне речи: квантна електродинамика, квантна хромодинамика, квантна теорија поља, ренормализациона група, бета функција.

Paper received on / Дата получения работы / Датум пријема чланка: 05.03.2021. Manuscript corrections submitted on / Дата получения исправленной версии работы / Датум достављања исправки рукописа: 30.12.2021.

Paper accepted for publishing on / Дата окончательного согласования работы / Датум коначног прихватања чланка за објављивање: 31.12.2021.

(c) 2022 The Authors. Published by Vojnotehnički glasnik / Military Technical Courier (http://vtg.mod.gov.rs, http://втг.мо.упр.срб). This article is an open access article distributed under the terms and conditions of the Creative Commons Attribution license (http://creativecommons.org/licenses/by/3.0/rs/).

() 2022 Авторы. Опубликовано в "Военно-технический вестник / Vojnotehnički glasnik / Military Technical Courier" (http://vtg.mod.gov.rs, http://втг.мо.упр.срб). Данная статья в открытом доступе и распространяется в соответствии с лицензией "Creative Commons" (http://creativecommons.org/licenses/by/3.0/rs/).

() 2022 Аутори. Објавио Војнотехнички гласник / Vojnotehnički glasnik / Military Technical Courier (http://vtg.mod.gov.rs, http://втг.мо.упр.срб). Ово је чланак отвореног приступа и дистрибуира се у складу са Creative Commons лиценцом (http://creativecommons.org/licenses/by/3.0/rs/).

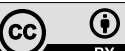

